\title{
Epigastric Vein
}

National Cancer Institute

\section{Source}

National Cancer Institute. Epigastric Vein. NCI Thesaurus. Code C53045.

Either of two veins including the inferior and superior epig astric veins. 